\title{
Reimbursement measures in European countries - findings of a bibliometric literature review
}

\author{
Sabine Vogler ${ }^{1}$, Nina Zimmermann ${ }^{1}$, Antonio Olry de Labry ${ }^{2 *}$, Jaime Espin ${ }^{2}$ \\ From 3rd International PPRI Conference 2015: Pharmaceutical Pricing and Reimbursement Policies: Challenges \\ Beyond the Financial Crisis \\ Vienna, Austria. 12-13 October 2015
}

\section{Background}

Policy-makers aim to achieve the partially conflicting objectives of equitable access to medicines, cost containment and sustainable funding as well as reward for innovation. To do so, a range of policy options is available that has been extended in recent years to meet new challenges.

\section{Objectives}

To identify existing pharmaceutical reimbursement policy options in European countries

\section{Methods}

A literature review was carried out using thesaurus and free terms in several databases and grey literature. Setting: Out-patient and in-patient sectors including possible measures at the interface of out-patient and in-patient sectors and stakeholders involved: State (as regulator), third party payers and patients (funders); pharmaceutical industry. Inclusion criteria: Studies or documents published between 1993 and February 2013 in all European Union (EU) languages performed in all 28 EU Member States and European Economic Area.

\section{Results}

In total 244 publications were selected, $61 \%$ of the selected studies were published between 2007 and 2011. Most literature referred to a sole country, particularly to large countries such as the UK and Germany. Descriptive work constituted a major body of literature; an impact assessment of policy measures was undertaken in $29 \%$ of the publications.

\footnotetext{
* Correspondence: antonio.olrylabry.easp@juntadeandalucia.es

${ }^{2}$ Escuela Andaluza de Salud Pública / Andalusian School of Public Health,

Campus Universitario de Cartuja, Granada, 18011, Spain

Full list of author information is available at the end of the article
}

The five reimbursement policies most frequently mentioned were: co-payments (mentioned in $51 \%$ of the selected publications); reimbursement rates (45\%); reference price systems (43\%); positive lists (43\%) and the reimbursement process (40\%). More than every second publication addressed either HTA or pharmacoeconomics. Generic substitution, reimbursement reviews, tendering and INN prescribing were identified in $35 \%-22 \%$ of the included publications. Nine per cent of the publications referred to managed-entry agreements, and 7\% mentioned value-based pricing. Reimbursement policies addressed in low frequency were auction-like systems, profit control or delisting from reimbursement.

\section{Conclusions}

Standard elements of reimbursement systems in European countries were identified in several publications, whereas newer policy options were covered less frequently in literature. Discussions about tools on how to best assess the value of (new) medicines are recurring in literature.

The literature reflects, with some publication delay, the approaches of policy-makers with regard to pharmaceutical reimbursement measures. In the 1990s and early years of the new millennium, descriptive studies about national reimbursement systems were predominant, supplemented, at a later stage, by descriptions and analyses of generic policies. In the new millennium, discussions about value assessments and the importance of HTA and pharmacoeconomics, frequently understood as a contrast to the pricing policy of external price referencing, were found. Policy options for new, high-priced medicines were particularly addressed in literature of recent years. 


\section{Acknowledgements}

The research was part of a study funded by the Consumers, Health and Food Executive Agency (CHAFEA) of the European Commission (Health Programme 2008-2013).

\section{Authors' details}

'WHO Collaborating Centre for Pharmaceutical Pricing and Reimbursement Policies, Health Economics Department, Gesundheit Österreich GmbH (Austrian Public Health Institute), Vienna, 1010, Austria. ${ }^{2}$ Escuela Andaluza de Salud Pública / Andalusian School of Public Health, Campus Universitario de Cartuja, Granada, 18011, Spain.

Published: 5 October 2015

doi:10.1186/2052-3211-8-S1-P21

Cite this article as: Vogler et al.: Reimbursement measures in European countries - findings of a bibliometric literature review. Journal of Pharmaceutical Policy and Practice 2015 8(Suppl 1):P21.

Submit your next manuscript to BioMed Central and take full advantage of:

- Convenient online submission

- Thorough peer review

- No space constraints or color figure charges

- Immediate publication on acceptance

- Inclusion in PubMed, CAS, Scopus and Google Scholar

- Research which is freely available for redistribution

Submit your manuscript at www.biomedcentral.com/submit 